To the October number of Symons's Monthly Meteorological over the valley below. There were several feals of thunder, but Magazine Col. Foster Ward writes describing some remarkable there was no visible lightning, owing, he concludes, to the sun's hailstones that fell during a slight thunderstorm at Partenkirchen, brightness. "On arriving near home, I met a friend who told Bavaria, at 6 p.m. on August 21. He was on a mountain about me it had been hailing 'tadpoles' and 'acidulated drops. 3000 feet abcve the village, and saw the cloud (a small one) pass There had been little or no rain and no visible lightning, and

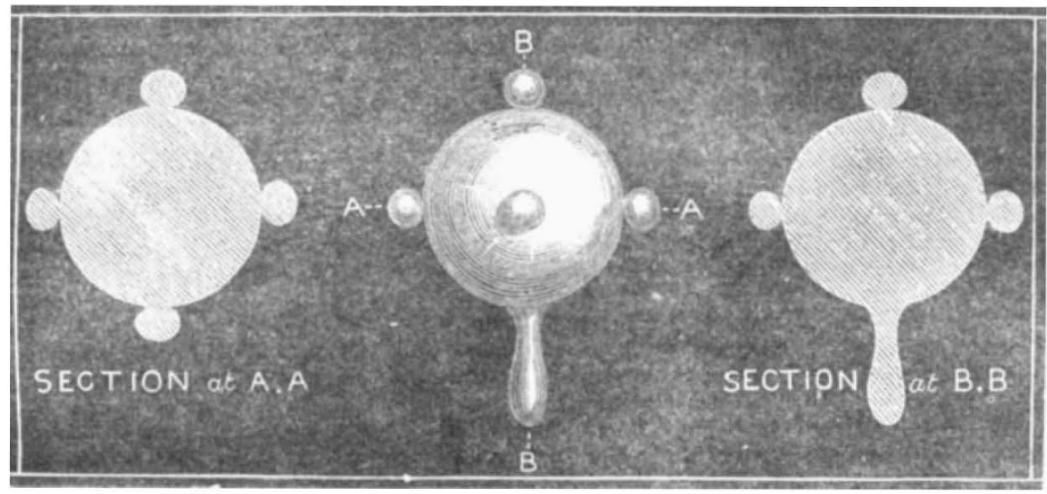

the bailstones fell at intervals and about six feet apart. There were very few of them, my family only picking up twenty in a space occupied by a full-sized lawn tennis court. My son made a sketch of their shape and size, which I inclose. The greater part were of the 'tadpole' shape and were clear as glass, perfectly round, the five knobs being at equal distance from one another. The flat stones had more or less a slight nucleus of snow in the convex portion of the stone. My wife and three daughters, and two ladies staying with us, say that the stones looked just like a lady's hand looking-glass, with a knob at the top and on either

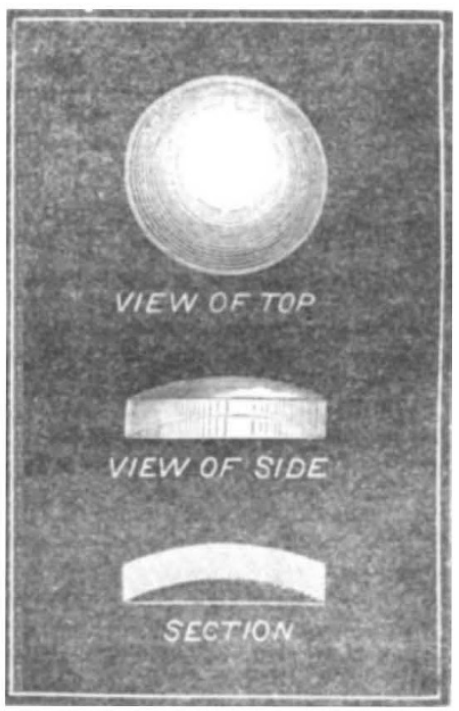

side for ornament. More than twenty, perhaps thirty, were picked up of this shape. Of these about two-thirds were studded, "the rest plain, with only the tail or handle, the thinnest part of it being near the body of the store, as in sketch. The studs were all symmetrically placed. There were from three to five in each stone besides the bandle. When there were less than five they occupied the same positions as if the five had been comIlete. In some cases the handle appeared to have been knocked off. The drops were more numerous, were all of same shape, convex at the top, the bottom being concave (like a small china painting palette)."
THE total completion of the St. Gothard tunnel will very likely take place in July of this year; the railway is to be opened on July 1, I882. The mail-bags are even now carried through the tunnel by messengers when ro: gh weather prevails upon the mountain. On December 2I the first mail-bag was so carried through the tunnel, and it took four hours to convey it from CErschenen to Airolo.

\section{GEOGRAPHICAL NOTES}

AT the Second International Polar Conference at Berne all the leading nations of Europe were represented except England. The leading stations have been definitely decided on. Austria undertakes to establish a station in northern Novaya Zemlya, at the expense of Count Wilczek; Denmark has selected Upernivik; Germany New Gecrgia for the Antarctic, and Jan Mayen or East Greenland for the Arctic regions; Norway, Bossekop in Finmark; Holland the south-east coast of Novaya Zemlya, or the coast of Siberia, between the mouth of the Yenissei and Cafe Taimyr; Russia has selected two stations, the mouth of the Lena and the New Siberian Islinds. Even Switzerland, which has not even a sea-board, hopes to take part in the international movement, by establishing a station at Mossel Bay, in Spitzbergen. The expedition to be sent out by Italy to the Antarctic region under Lieut. Bove is to some extent connected with this scheme, and no doubt France will ultimately be compelled to take her part. As to England, there has hitberto been no sign that as a nation she is even interested in a scheme so full of important issues for science and navigation.

IN a recent paper to the $R$. Accademia dei Lincei, Signor Guido Cora, a member of the International Polar Commi tee, urges the importance of the enterprise under consideration, and of Italy sharing in it. $\mathrm{He}$ considers the Antarctic zone as the more suitable one for Italy, as being nearer regions where Italians form a large portion of the population and conduct an extensive commerce; moreover the south has a brilliant record of geographical exploration by Italians in the sixteenth century, and the recent project of an Antarctic exploring expedition has drawn enthusiastic attention. For the temporary scientific observatory uhich the Italian Government is recommended to plant in 1882 (in harmony with the large scheme), S. Cora suggests one or other of three places:-1. Port Spence, on the east coast of Coronation Is'and in the Southern Orkneys, at about $60^{\circ} 50^{\prime} \mathrm{S}$. lat., and $45^{\circ} 45^{\prime} \mathrm{W}$. long. 2. Cape Look. out, on the south coast of Elephant Island, in the north-east part of the Southern Shetland group, at about $6 \mathrm{r}^{\circ} 17^{\prime} \mathrm{S}$. lat and $55^{\circ} 15^{\prime} \mathrm{W}$. long. (a station at either place would serve well as a base of operations for the Italian Exploring Expedition). 3. In the case of means being inadequate for a station at either of the two places named, S. Guido recommends some one of the islands close to Cape Horn. Supposing that the transport would be by a Government vessel destined to the naval station 
in South America, it is calculated that the cost of the observatory would amount to 70,000 or 80,000 lire, of which 10,000 would be for instruments, and the remainder would provide three dwellinghouses, salaries of four scientists, two assistants, and two servants, food, \&c. This is calculated for an absence of sixteen months, twelve of which would be occupied in observations.

THE Geographical Society's Proceedings this month contains three papers relating to Africa, the first of which is Sir Bartle Frere's, on Temperate South Africa. This, as now printed, embodies some useful statistical information and is illustrated by a general map of South Africa. The other two papers bring some additions to our knowledge of the geography of West Africa, Mr. Comber giving a short sketch of his recent journeys in the interior of Congo, and Mr. Milum an account of his travels in the Niger region. The former is accompanied by an excellent map of the neighbourhood of San Salvador and of the course of the River Congo from Stanley Ponl to the sea. The final report of the Executive Committee of the African Exploration Fund is published, together with a statement of receipts and expenditure. In the Geographical Notes extracts are given from a letter by $\mathrm{Mr}$. Hore of Ujiji, on the long-continued rise of the waters of Lake Tanganyika, which he seems to connect with earthquake-movements. Mr. Hore is shortly about to return to England, so that we shall probably hear more on this subject before long. Among the other notes we may call attention to thcse on the River Okavango, the survey of Eastern Palestine, and the United States' Survey operations in the neighbourhood of Behring Strait. Increased attention, we note, is being paid to the proceedings of foreign geographical Societies, those of the French Society being yery fully reported.

M. Vossron, who, it will be remembered, spent some time in Burmah, and not long since read papers on that country before the French Greographical Societies, has lately gone to Egypt to take up the Vice-Consulship of Khartum. During his stay there he is to pay special attention to the slave trade, and to the best means of opening up commercial relations with the Sudan.

Capt. Serra-Carracioli left Naples on November 23, r88o, for the Bay of Assab, having undertaken a mission, under the auspices of the Club Africano, to inquire into the possibility of developing commerce there and with the natives of the interior The Club Africano is desirous of establishing pearl, mother-ofpearl, and sponge fisheries in the Bay of Assab. While funds are being raised for more extensive operations, this expedition is sent out to make a careful survey of the region, to form a depôt for further expeditions, whether commercial or scientific, and to make other preparations. The expense is expected not to exceed $600 l$. It is also stated that the Italian Geographical Society have made arrangements for the establishment of a meteorological station at the Bay of Assab. The October part of the Bolletino of the Italian Geographical Society contains a long and valuable memoir by Signor C. de Amezaga on Assab.

AT the last meeting of the Lyons Geographical Society M. Coillard gave an interesting account of his twenty years' experiences in South Africa. He was engaged for some time on a missionary expedition in the Upper Zambesi region, and was probably the means of saving Major Serpa Pinto's life, afterwards accompanying him in some of his explorations. As no particulars have yet been published of M. Coillard's geographical work in this region, it is to be boped that his paper will be given in full in the Lyons Society's Bulletin.

In last week's Missions Catholiques we have the concluding instalment of some interesting and useful papers iby the Bishop of Vancouver, entitled "Une Visite Pastorale dans le Territoire d'Alaska." Père Montiton's notes on the traditions and customs of the Sandwich Islands are also cuntinued.

THE January number of Good Words contains the first of a series of papers by Mr. Joseph Thomson on his experiences during his recent journey in East Central Africa. The present instalment deals with the preparatory journey which he made with $\mathrm{Mr}$ Keith Johnston to Usambara, and furnishes interesting notes on the country traversed.

The Alexandria Correspondent of the Daily News tells us that M. Chower, formerly a newspaper correspondent in Turkey, Kurdistan, Armenia, and Albania, started on December 3I, "to explore Africa from north to south, from Alexandria to the Cape of Good Hope." Bon voyage.

THE death is announced of Dr. Fr. Mook, the wrll.krowis African traveller, who accompanied Dr. E. Riebeck on his expedition, which started in August last for the East. Dr. Mook died at Jaffa shortly before Christmas.

WE have received parts 17 to 22 of the new edition of Stieler's Hand-Atlas, with three supplementary parts containing in eight sheets a very fine map of the Basin of the Mediterranean Sea.

THE Dutch Committee, which arranged the North Polar Expeditions of the last few years, held a general meeting at the Hague a short time ago, when the resolution was passed to collect funds for the organisation of a fourth Arctic expedition. In the meantime the Committee will endeavour to have a steamer built for this purpose.

\section{ON HEAT CONDUCTION IN HIGHLY RAREFIED AIR}

THE transfer of heat across air of different densities has been examined by various experim ntalists, the general result being that heat conduction is almost independent of pressure. Winkelmann (Pogg. Ann. 1875, 76) measured the velocity of cooling of a thermometer in a vessel filled with the gas to be examined. The difficulty of these experiments lies in the circum. stance that the cooling is caused not only by the conduction of the gas which surrounds the cooling body, but that also the currents of the gas and, above all, radiation play an important part. Winkelmann eliminated the action of currents by altering the pressure of the gas between 760 and I millim. (with decreasing pressure the action of gas currents becomes less); and he obtained data for eliminatirg the action of radiation by varying the dimensions of the outer ves el. He found that, whereas a lowering of the pressure from 760 to $9 \mathrm{r}^{\circ} 4$ millims. there was a change of only I' 4 per cent. in the value for the velocity of cooling, on further diminution of the pressure to 4.7 millims. there was a further decrease of is per cent., and this decrease continued when the pressure was further lowered to $I^{\circ} 92$ millim.

About the same time Kundt and Warburg (Pogg. Ann. 1874, 5) carried out similar experiments, increasing the exhaustion to much higher points, but without giving measurements of the pressure below I millim. They inclosed a thermometer in a glass bulb connected with a mercury pump, and heated it to a higher tem. perature than the highest point at which observations were to be taken; then left it to itself, and noted the time it took to fall through a certain number of degrees. They found that between ro millims. and I millim. the time of cooling from $60^{\circ}$ to $20^{\circ}$ was independent of the pressure; on the contrary, at I 50 millims. pressure the rate was one-and-a-half times as great as at 750 millims. Many precautions were taken to secure accuracy, but no measurements of higher exhaustions being given the resnlts lack quantitative value.

It appears, therefore, that a thermometer cools slower in a so. called vacuum than in air of atmospheric pressure. In dense air convection currents have a considerable share in the action, but the law of cooling in vacua so high that we may neglect convection has not to my knowledge been determined. Some years ago Prof. Stokes suggested to me to examine this point, but finding that Kundt and Warburg were working in the same direction it was not thought worth going over the same ground, and the experiments were only tried up to a certain point, and then set aside. The data which these experiments wonld have given are now required for the discussion of some results on the viscosity of gases, which I hope to lay before the Society in the course of a few weeks; I have therefore completed them so as to embody the results in the form of a short paper.

An accurate thermometer with pretty open scale was inclosed in a $\mathrm{I} \frac{1}{2}$ inch glass globe, the bulb of the thermometer being in the centre, and the stem being inclosed in the tube leading from the glass globe to the pump.

Experiments were tried in two ways:-

I. The glass globe (at the various exhaustions) was immersed in nearly boiling water, and when the temperature was stationary it was taken out, wiped dry, and allowed to cool in the air, the number of seconds occupied for each sink of $5^{\circ}$ being noted.

II. The globe was first brought to a uniform temperature in a vessel of water at $25^{\circ}$, and was then suddenly plunged into a large vessel of water at $65^{\circ}$. The bulk of hot water was such that the temperature remained sensibly the same during the continuance of each experiment. The number of seconds required for the thermometer to rise from $25^{\circ}$ to $50^{\circ}$ was registered as in the first case.

${ }^{I}$ Abstract of a Paper read before the Royal Society by William Crookes, F. R.S., December 16 , 1880 . 